\title{
Bone marrow culture in aplastic anaemia
}

\author{
A. J. BARRETT ${ }^{1}$, A. FAILle, N. BALITRAND, F. KETELS, AND Y. NAJEAN \\ From the Institut des Recherches sur les Maladies du Sang, Centre G. Hayem, Hôpital Saint-Louis, \\ 2, Place du Docteur Alfred Fournier, Paris 75010, France
}

SUMMARY Blood and bone marrow granulocyte colony forming units $\left(C F U_{C}\right)$ were assayed in 46 patients with aplastic anaemia, and the serum was examined for its inhibitory action on normal $\mathrm{CFU}_{\mathrm{C}}$ growth. All patients showed a gross reduction in colonies and clusters in incidence and absolute number in the bone marrow and blood. Two proliferative abnormalities of $\mathrm{CFU}_{\mathbf{C}}$ in aplastic anaemia were identified: a significantly higher than normal cluster to colony ratio $(P<0.05)$ and a higher than normal ratio of granulocytes to total aggregates in the bone marrow.

Eleven out of 34 patients tested had serum inhibitory to normal CFU $\mathrm{C}_{\mathrm{C}}$. These patients were indistinguishable from the rest on haematological and $C F U_{C}$ culture characteristics, and no correlation between the results of $\mathrm{CFU}_{\mathrm{C}}$ assay and haematological severity was found.

The results suggest that the $\mathrm{CFU}_{\mathrm{C}}$ is abnormal in aplastic anaemia, the reduction in pool size being related to a failure of self-renewal, but an immunological role in the pathogenesis of aplastic anaemia remains unproven.

The close relationship of $\mathrm{CFU}_{\mathrm{C}}$ incidence to the percentage of granulocyte precursors in the marrow, together with the failure of the $\mathrm{CFU}_{\mathrm{C}}$ assay to predict clinical severity, limits the practical use of the assay to the confirmation of diagnosis in aplastic anaemia.

The assay of granulocyte progenitor cells $\left(C F U_{C}\right)$ by the soft agar colony forming technique has demonstrated that patients with aplastic anaemia have grossly reduced numbers of granulocyte precursors in the bone marrow and blood (Greenberg and Schrier, 1973; Kern et al., 1977). The evidence from clinical bone marrow transplantation suggests that there is primary stem cell failure in aplastic anaemia (Storb et al., 1974; Singer et al., 1978). However, some data support a bone marrow microenvironmental defect (Knospe and Crosby, 1971; Fernbach and Trentin, 1977) and, at least in some patients, an autoimmune process in the disease (Ascensão et al., 1976; Kagan et al., 1976; Speck et al., 1977; Te Velde and Haak, 1977; Gluckman et al., 1978).

We studied a large group of patients with aplastic anaemia to look for clues to the aetiopathogenesis of this condition:

1 comparing the relationship of $\mathrm{CFU}_{\mathrm{C}}$ to blood and bone marrow findings in normal subjects and aplastic anaemia patients in an attempt to define

${ }^{1}$ Present address: Department of Haematology, Westminster Medical School, London SW1

Received for publication 14 December 1978 subgroups of patients with particular $\mathrm{CFU}_{\mathrm{C}}$ characteristics; and

2 determining the $\mathrm{CFU}_{\mathrm{C}}$ and haematological characteristics of patients found to have serum inhibitory to normal bone marrow $\mathrm{CFU}_{\mathrm{C}}$.

In addition, we examined the practical contribution of bone marrow culture to establishing the diagnosis and severity of aplastic anaemia.

\section{Patients and methods}

PATIENTS

Forty-six patients with aplastic anaemia (27 male and 19 female; mean ages 25 and 22) referred to the Hôpital Saint Louis between April 1976 and October 1977 were studied. In five patients a toxic cause for the aplastic anaemia was suspected, three had aplasia following hepatitis, and in the rest no aetiological cause was identified. The diagnosis of aplastic anaemia was made on repeated blood counts showing pancytopenia and greatly reduced bone marrow cellularity on biopsy. There was a bias towards referral of patients fulfilling the diagnostic criteria of severe aplasia: 30 patients had a reticulocyte count of less than $20 \times 10^{9} / 1$, a neutrophil count of less than $0.5 \times 10^{9} / 1$, and a platelet count of less than $20 \times 10^{9} / 1$. 


\section{Colony assays}

These were performed soon after admission to the unit before specific treatment had begun, but most patients had already received androgen treatment before referral, and all had received blood transfusions.

\section{Serum}

Serum for inhibitor studies was taken at the same time as the marrow sample and stored at $-80^{\circ} \mathrm{C}$ until tested.

\section{Normal bone marrow and blood samples}

Samples were obtained from bone marrow transplant donors and from patients undergoing diagnostic bone marrow aspiration for non-haematological disorders. Blood samples for colony assays were obtained from healthy laboratory workers and blood donors.

\section{CFUC CULTURE}

The technique of Pike and Robinson (1970) was used. In particular, triplicate cultures were prepared for each sample, and feeder layers of $10^{6}$ normal buffy coat leucocytes were used as a source of colony stimulating factor. Marrow and blood samples were separated on Lymphoprep (Nygaard), and the washed separated mononuclear cells were cultured in McCoy's 5A medium in $0.3 \%$ agar at a concentration of $2 \times 10^{5}$ cells/culture plate for marrow and $5 \times 10^{5}$ cells/culture plate for blood. Cultures were incubated for 10 days in $5 \% \mathrm{CO}_{2}$ and high humidity. Colonies (groups of 50 or more cells) and clusters (groups of 5-49 cells) were counted using an inverted objective microscope, and results were expressed as the mean of triplicate cultures.

\section{Serum}

Serum was assayed for its inhibitory effect by preincubating $8 \times 10^{5}$ normal bone marrow mononuclear cells in the presence of $10 \%$ test serum and $10 \%$ rabbit complement for $1 \frac{1}{2}$ hours at $37^{\circ} \mathrm{C}$. The marrow cells were washed, suspended in agar and medium, and plated in triplicate at a final concentration of $2 \times 10^{5}$ cells/culture plate. Colony inhibition was expressed as the index: mean colony number after exposure to test serum

mean colony number after exposure to autologous serum

Normal serum gave a range of $1.03 \pm 0.28$ (2SD) (Barrett et al., 1978).

STATISTICAL ANALYSIS

The results were analysed using the Student's $t$ test and the Wilcoxon Rank sum test.

\section{Results}

Figure 1 shows the haematological characteristics of the patients studied together with the colony assay results. Bone marrow and blood colony and cluster growth were grossly reduced in all patients, six patients having no detectable growth in marrow or blood. Table 1 compares these results with those of 40 normal bone marrow cultures. Blood and bone marrow colony and cluster numbers in aplastic anaemia patients were significantly lower either when expressed as growth in relation to cell concentration plated or as absolute colony or cluster numbers per millilitre of blood or marrow aspirate. In addition, the ratio of clusters to colonies in the bone marrow was significantly higher in patients with aplastic anaemia (Table 1).

Sera from 34 patients were tested for ability to inhibit $\mathrm{CFU}_{\mathrm{C}}$ growth of normal bone marrow (Fig. 2).

Patients with aplastic anaemia showed a wide scatter of results between an index of $+1 \cdot 2$ to 0.0 (that is, total inhibition). Eleven patients had indices of 0.55 or less, and, for the purpose of analysis, these patients were designated as a group showing CFU $U_{C}$ inhibition.

\section{COMPARISON OF CULTURE RESULTS WITH} BONE MARROW FINDINGS

Figure 3 shows the relationship between total aggregate incidence and percentage of bone marrow granulocytes (myeloblasts plus promyelocytes plus myelocytes plus metamyelocytes). There was a positive correlation of $C F U_{C}$ with the bone marrow granulocyte percentage $(r=0.42, P=0.4$ (normals)

Table 1 P values derived from Wilcoxon unpaired Rank sum test

\begin{tabular}{llllll}
\hline & Colonies $/ 2 \times 10^{5}$ cells & Total aggregates/2 $\times 10^{5}$ cells & Colonies/ml & Total aggregates/ml & Cluster: colony ratio \\
\hline Blood & $<0.01$ & $<0.01$ & $<0.01$ & $<0.01$ \\
Marrow & $<0.01$ & $<0.001$ & $<0.001$ & $<0.001$ & $<0.05$ \\
\hline
\end{tabular}

Bone marrow CFUc -46 patients with aplastic anaemia; 40 normal subjects

Blood CFU C-19 patients with aplasia; 29 normal subjects 


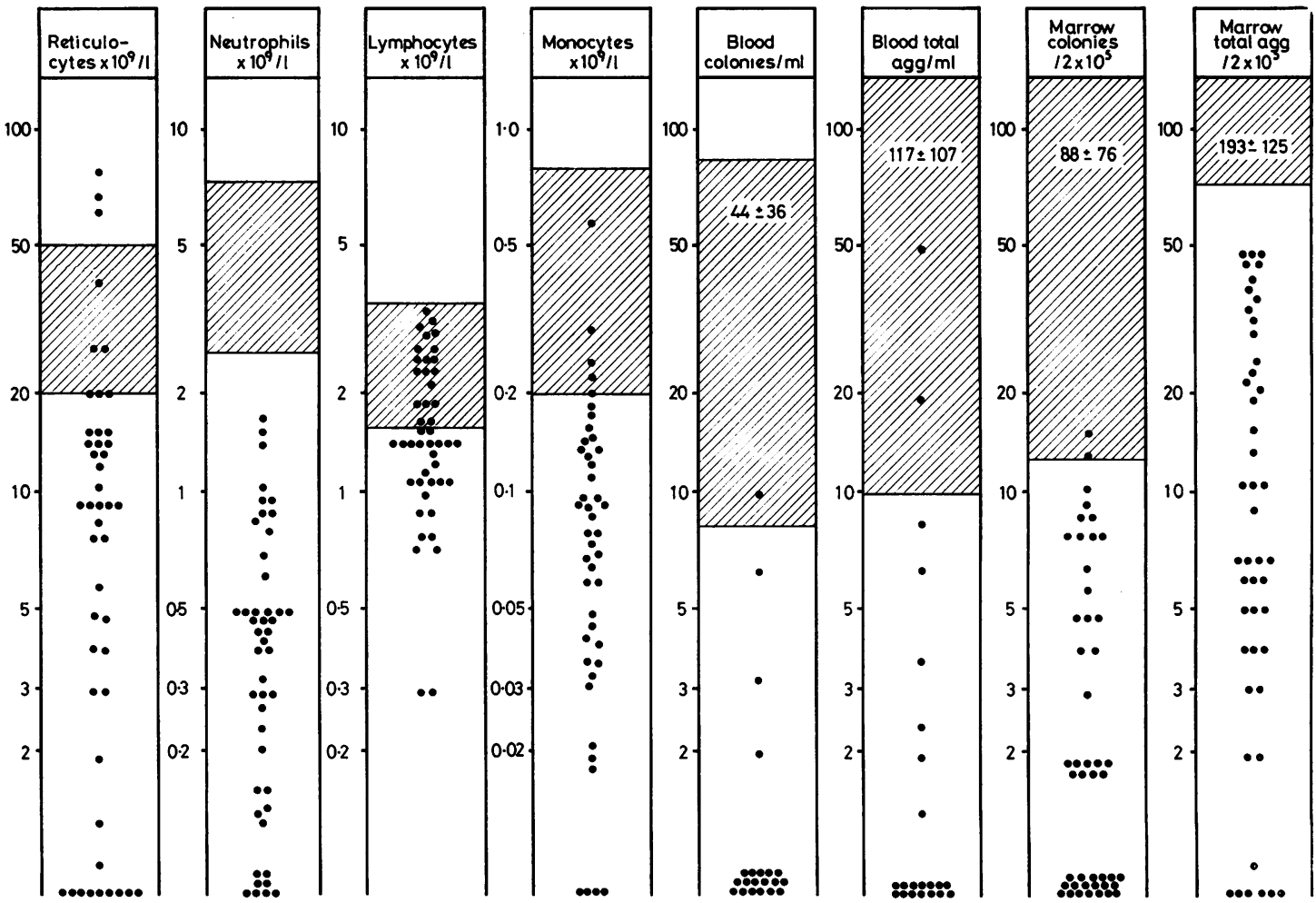

Fig. 1 Haematological and granulocyte culture characteristics of patients with aplastic anaemia compared with normal (normal ranges for haematological indices taken from Dacie and Lewis (1975)). Twenty-nine normal blood samples and 40 haematologically normal bone marrows cultured in the same laboratory under identical conditions were used as controls for $\mathrm{CFU}$ C results. Shaded area represents \pm one standard deviation of normal range.

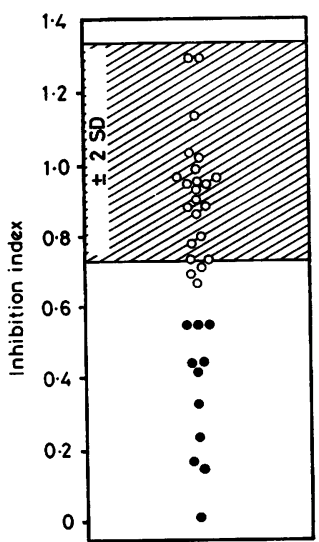

Fig. 2 Effect of serwm on normal $C F U_{C}$ growth in 34 patients with aplastic anaemia. Inhibition; O No inhibition. and $r=0.42, P=0.01$ (aplastic anaemia)). The slope of the regression lines differed, patients with aplastic anaemia having significantly lower ratios of total aggregate to granulocytes $(t=2 \cdot 2, \mathrm{P}=0.05)$.

Figure 4 shows the relationship between total aggregate incidence and percentage of bone marrow lymphocytes. In aplastic anaemia there was an inverse correlation between the lymphocyte percentage and the total aggregates per $2 \times 10^{5}$ cells plated. The data best fitted an exponential distribution $(r=0.48, P=0.001)$, but normal subjects showed no significant relationship of lymphocytes to total aggregates. There was no obvious segregation of data from patients with serum inhibitory to CFUC.

RELATIONSHIP OF COLONY COUNTS TO HAEMATOLOGICAL SEVERITY

Table 2 shows that there was no significant difference 


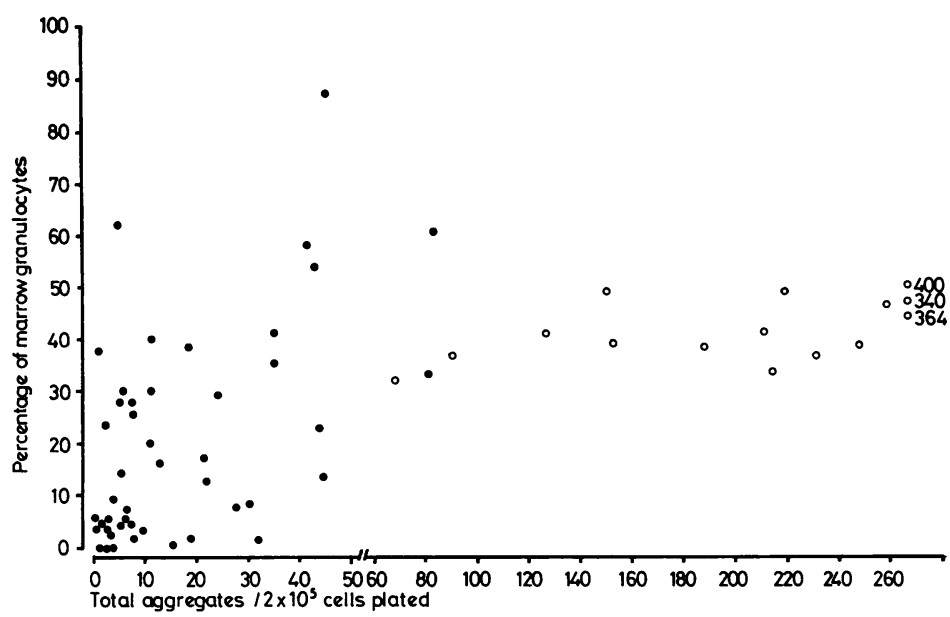

Fig. 3 Relationship of bone marrow granulocyte percentage to incidence of total aggregates in aplastic anaemia patients and 15 normal subjects: 1 aplastic anaemia patients; $\bigcirc$ normal subjects.

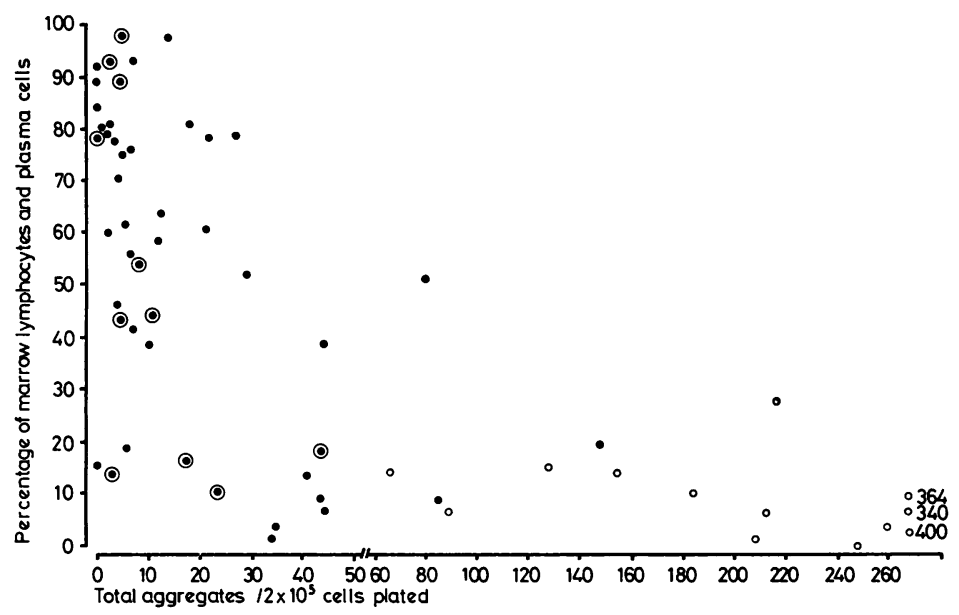

Fig. 4 Relationship of marrow lymphocyte and plasma cell percentage to incidence of total aggregates in aplastic anaemia patients and 15 normal subjects: aplastic anaemia patients; $\bigcirc$ normal subjects; $\bigcirc$ patients with serum inhibitors to $C F U_{C}$.

Table 2 Comparison of severe aplasia $\mathrm{v}$ less severe aplasia $C F U_{C}$ characteristics

\begin{tabular}{llll}
\hline & $\begin{array}{l}\text { Colonies/ } \\
2 \times 10^{5} \text { cells }\end{array}$ & $\begin{array}{l}\text { Total } \\
\text { aggregates/ } \\
2 \times 10^{5} \text { cells }\end{array}$ & $\begin{array}{l}\text { Total } \\
\text { aggregates } /\end{array}$ \\
\hline $\begin{array}{llll}\text { ml } \\
\text { Severe aplasia }\end{array}$ & $\begin{array}{l}4 \cdot 7 \pm 1 \cdot 1 \\
(0-27)\end{array}$ & $\begin{array}{l}14 \pm 3 \cdot 3 \\
(0-84)\end{array}$ & $\begin{array}{l}200 \pm 63 \\
(0-1347)\end{array}$ \\
$\begin{array}{l}\text { Mean } \pm \text { SEM (range) } \\
\text { (33 patients) }\end{array}$ & $\begin{array}{l}4 \cdot 3 \pm 1 \cdot 2 \\
\text { Less severe aplasia } \\
\text { Mean } \pm \text { SEM (range) } \\
(13 \text { patients) }\end{array}$ & $\begin{array}{l}18 \pm 3 \cdot 6 \\
(0-81)\end{array}$ & $\begin{array}{l}476 \pm 181 \\
(0-2970)\end{array}$ \\
\hline
\end{tabular}

$P>0 \cdot 1$ for: colonies $/ 2 \times 10^{5}$ cells, total aggregates $/ 2 \times 10^{5}$ cells, and total aggregates/ml using Wilcoxon Rank sum tests.

in culture results between severe and less severe aplastic anaemia. Similarly, it was not possible to distinguish different haematological features of six patients who had no colony growth when compared with 17 who showed only cluster growth and 23 who had colony and cluster growth (Table 3 ).

\section{RELATIONSHIP OF SERUM INHIBITORS TO SEVERITY}

Table 4 shows that no significant difference was found between the proportion of bone marrow lymphocytes, the blood lymphocytes, and the CFU $_{\mathbf{C}}$ characteristics of patients with inhibitors compared with those without.

\section{Discussion}

Our results confirm in a large series of patients the characteristic paucity of colony and cluster growth in aplastic anaemia (Greenberg and Schrier, 1973; Kern et al., 1977). 
Table 3 Haematological variation according to CFU $U_{C}$ culture characteristics

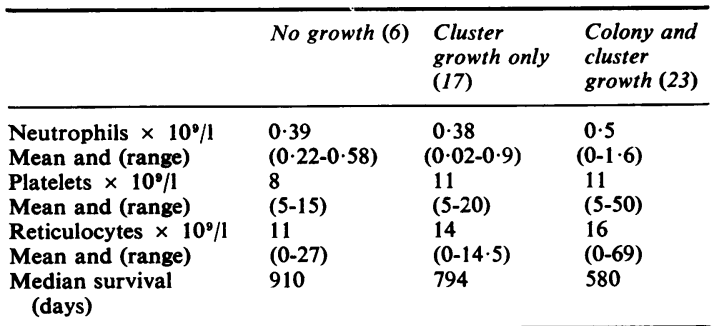

No significant difference was found on Wilcoxon Rank sum tests between: no growth $v$ cluster growth only; cluster growth only $v$ colony and cluster growth; and no growth $v$ colony and cluster growth ( $P>0.1$ for each test)

In addition, we have also identified qualitative abnormalities that distinguish $\mathrm{CFU}_{\mathrm{C}}$ in aplastic anaemia from normal. The ratio of clusters to colonies was higher in aplastic anaemia, as was the ratio of bone marrow granulocytes to the incidence of total aggregates.

These features could be interpreted as indicating stem cell damage which impairs their capacity both for proliferation (hence greater numbers of clusters than colonies) and for self-renewal (hence a small stem cell pool and the increased ratio of mature cells to $\mathrm{CFU}$ ).

We also found inhibitors of normal bone marrow $\mathrm{CFU}_{\mathrm{C}}$ in about one-third of the patients. While serum inhibitors of $\mathrm{CFU}_{\mathrm{C}}$ are found in polytransfused patients with other disorders (Barrett et al., 1978) we have shown that they are associated with a beneficial response of aplastic anaemia patients to ALG treatment (Faille et al., 1979), and one report (Gordon, 1978) of inhibition by the patient's serum of bone marrow $\mathrm{CFU}_{\mathrm{C}}$ from an identical twin suggests that, at least in some instances, serum inhibitors in aplastic anaemia are directly related to the aplastic process and not to sensitisation by blood transfusion.

We were unable to distinguish the 11 patients with serum inhibitors from the rest of the group by either haematological severity or culture charac- teristics. This suggests that although serum inhibitors may possibly represent a marker of an immunological cause for the aplastic anaemia, the subsequent marrow failure is indistinguishable in nature and severity from the aplasia induced by other processes.

There are several possible interpretations for the inverse relationship between bone marrow $\mathrm{CFU}_{\mathrm{C}}$ incidence and marrow lymphocyte percentage in aplastic anaemia. The severity of the aplasia has been related to the degree of lymphocyte infiltration on marrow histology (Te Velde and Haak, 1977) but marrow lymphocytosis may simply reflect the absence of normal myeloid precursor cells. It has been claimed that lymphocytes from patients with aplastic anaemia can inhibit normal $\mathrm{CFU}_{\mathrm{C}}$ in co-culture (Kagan et al., 1976; Haak and Goselink, 1977), but the validity of the co-culture technique to demonstrate specific abnormalities in aplastic anaemia has been challenged (Singer et al., 1978). Further studies are required to demonstrate any association between the in vitro findings of lymphocyte inhibitors and the characteristics of the bone marrow lymphocytosis and $\mathrm{CFU} \mathrm{C}_{\mathrm{C}}$ content.

Lastly, from a practical viewpoint, while colony assay may confirm the diagnosis of aplastic anaemia, the technique does not identify different degrees of severity of the condition. Furthermore, since CFU $\mathrm{C}_{\mathrm{C}}$ correlated directly with the percentage of bone marrow granulocytes, little additional information is obtained from bone marrow culture that cannot be obtained from examination of the bone marrow aspirate.

This work was carried out during tenure of a Leukaemia Research Fund/-INSERM Anglo-French Exchange Fellowship by A. J. Barrett.

We thank Angela Tasker for typing the manuscript.

\section{References}

Ascensão, J., Pahwa, R., Kagan, W., Hansen, J., Moore,

Table 4 Haematological and $C F U_{C}$ characteristics of patients with and without serum inhibitors to $C F U_{C}$

\begin{tabular}{|c|c|c|c|c|c|c|}
\hline Patients & $\begin{array}{l}\text { Blood lymphocytes } \\
\times 10^{\circ} / l\end{array}$ & $\begin{array}{l}\text { Blood neutrophils } \\
\times 10^{\circ} / l\end{array}$ & $\begin{array}{l}\text { Marrow lymphocyte } \\
\text { percentage }\end{array}$ & $\begin{array}{l}\text { Colonies } / m l \\
\text { marrow aspirate }\end{array}$ & $\begin{array}{l}\text { Total aggregates } \\
2 \times 10^{5} \text { cells } \\
\text { plated }\end{array}$ & $\begin{array}{l}\text { Cluster: } \\
\text { colony ratio }\end{array}$ \\
\hline $\begin{array}{l}\text { Serum inhibitors } \\
\text { (11 patients) } \\
\text { Mean } \pm \text { SD } \\
\text { No inhibitors } \\
\text { (24 patients) } \\
\text { Mean } \pm \text { SD } \\
\text { Statistical difference } \\
\quad \text { (unpaired } t \text { tests) } \\
\text { NS = not significant }\end{array}$ & $\begin{array}{l}1.84 \\
\pm \\
0.75 \\
1.75 \\
\pm \\
0.79 \\
\text { NS }\end{array}$ & $\begin{array}{l}0.7 \\
\pm \\
0.5 \\
0.4 \\
\pm \\
0.3 \\
\text { NS }\end{array}$ & $\begin{array}{l}64 \\
\pm \\
31 \\
53 \\
\pm \\
29 \\
\text { NS }\end{array}$ & $\begin{array}{l}66 \\
\pm \\
58 \\
65 \\
\pm \\
60 \\
N S\end{array}$ & $\begin{array}{l}15 \cdot 7 \\
\pm \\
15 \\
22 \\
\pm \\
20 \\
\text { NS }\end{array}$ & $\begin{array}{l}2 \cdot 3 \\
\pm \\
1 \cdot 8 \\
1 \cdot 96 \\
\pm \\
1 \cdot 5 \\
\text { NS }\end{array}$ \\
\hline
\end{tabular}


M., and Good, R. (1976). Aplastic anaemia: evidence for an immunological mechanism. Lancet, 1, 669-671.

Barrett, A. J., Faille, A., Saal, F., Balitrand, N., and Gluckman, E. (1978). Marrow graft rejection and inhibition of growth in culture by serum in aplastic anaemia. Journal of Clinical Pathology, 31, 12441248.

Dacie, J. V., and Lewis, S. M. (1975). Practical Haematology, 5th edition, p. 12. Churchill Livingstone, Edinburgh.

Faille, A., Barrett, A. J., Balitrand, N., Ketels, F., Gluckman, E., and Najean, Y. (1979). Effect of antilymphocyte globulin on granulocyte precursors in aplastic anaemia. British Journal of Haematology, (in press).

Fernbach, D. J., and Trentin, J. J. (1977). Isologous bone marrow transplantation in an identical twin with aplastic anaemia. In Proceedings of the 8th International Congress of Hematology, Tokyo, Pan Pacific, 1960, p. 150.

Gluckman, E., Devergie, A., Faille, A., Barrett, A. J., Bonneau, M., Boiron, M., and Bernard, J. (1978). Treatment of severe aplastic anaemia with antilymphocyte globulin and androgen. Experimental Hematology, 6, 679.

Gordon, M. Y. (1978). Circulating inhibitors of granulopoiesis in patients with aplastic anaemia. British Journal of Haematology, 39, 491-496.

Greenberg, P. L., and Schrier, S. L. (1973). Granulopoiesis in neutropenic disorders. Blood, 41, 753-769.

Haak, H. L., and Goselink, H. M. (1977). Mechanisms in aplastic anaemia (Letter). Lancet, 1, 194.

Kagan, W. A., Ascensão, J. A., Pahwa, R. N., Hansen, J. A., Goldstein, G., Valera, E. B., Incefy, G. S., Moore, M. A. S., and Good, R. A. (1976). Aplastic anaemia-presence in human bone marrow of cells that suppress myelopoiesis. Proceedings of the National
Academy of Sciences (Washington), 73, 2890-2894.

Kern, P., Heimpel, H., Heit, W., and Kubanek, B. (1977). Granulocytic progenitor cells in aplastic anaemia. British Journal of Haematology, 35, 613-623.

Knospe, W. H., and Crosby, W. H. (1971). Aplastic anaemia; a disorder of the bone marrow sinusoidal microcirculation rather than stem cell failure? Lancet, 1, 20-22.

Pike, B. L., and Robinson, W. A. (1970). Human bone marrow colony growth in agar-gel. Journal of Cellular Physiology, 76, 77-84.

Singer, J. W., Brown, J. E., James, M. C., Doney, K., Warren, R. P., Storb, R., and Thomas, E. D. (1978). Effect of peripheral blood lymphocytes from patients with aplastic anemia on granulocytic colony growth from HLA-matched and mismatched marrows. Effect of transfusion sensitization. Blood, 52, 37-46.

Speck, B., Gluckman, E., Haak, H. L., and Van Rood, J. J. (1977). Treatment of aplastic anaemia by antilymphocyte globulin with and without allogeneic bone marrow infusions. Lancet, 2, 1145-1148.

Storb, R., Thomas, E. D., Buckner, C. D., Clift, R. A., Johnson, F. L., Fefer, A., Glucksberg, H., Giblett, E. R., Lerner, K. G., and Neiman, P. (1974). Allogeneic marrow grafting for treatment of aplastic anaemia. Blood, 43, 157-180.

Te Velde, J., and Haak, H. L. (1977). Aplastic anaemia. Histological investigation of methacrylate embedded bone marrow biopsy specimens; correlation with survival after conventional treatment in 15 adult patients. British Journal of Haematology, 35, 61-69.

Requests for reprints to: Dr A. J. Barrett, Haematology Department, Westminster Medical School, Dean Ryle Street, London SW1P 2AP, UK. 